\title{
MORTALITY FROM EXTERNAL CAUSES AMONG 1-14 YEARS OLD CHILDREN IN SERBIA, 1997-2016
}

\author{
Konstansa Lazarević1, Dragan Bogdanović ${ }^{1}$, Saša Milićević1, Zana Dolićanin ${ }^{1}$, Dragan Milić ${ }^{2}$ \\ 'Department for Biomedical Science, State University of Novi Pazar, Novi Pazar, Serbia \\ ${ }^{2}$ Medical faculty, University in Niš, Niš, Serbia
}

\section{SUMMARY}

Objectives: Globally, child mortality from external causes is in decline, but it is still among the leading causes of child deaths. The aim of this first national study was to determine trends of mortality rates from external causes among children aged 1-14 years in Serbia.

Methods: Mortality data were collected from the database of the Statistical Office of Serbia. Joinpoint analysis was used to assess the average annual percentage change (APC) and the corresponding 95\% confidence interval (CI) in mortality from 1997 to 2016.

Results: In the 1997-2016 period, there were 1,388 child deaths from external causes. They contributed to $29.4 \%$ of child mortality in total, from $34.8 \%$ in 1997 to $21.8 \%$ in 2016. Mortality rate was two times higher among boys ( 8.1 per 100,000) than girls $(4.1$ per 100,000). Transport accidents $(37.6 \%)$, followed by drowning and submersion (18.2\%), represented more than half of all deaths due to external causes. Since 1997 , mortality rate showed a significant downward trend in boys by $-5.4 \%(95 \% \mathrm{Cl}-6.8$ to -3.9$)$ yearly for unintentional injuries and significantly by $-10 \%(95 \% \mathrm{Cl}-19.0$ to 0.1$)$ yearly for intentional injuries. Among girls, death rate for unintentional injuries decreased significantly by $-7.1 \%(95 \%$ $\mathrm{Cl}-9.0$ to -5.1$)$ yearly and decreased insignificantly for intentional injuries by $-2.1 \%(95 \% \mathrm{Cl}-15.3$ to 13.1$)$ yearly.

Conclusions: The external causes of death, despite the substantial decline in mortality, are still present among children aged 1-14 years in Serbia. Therefore, implementation of nationwide programmes for prevention of external causes of death is urgent.

Key words: mortality, external causes, children

Address for correspondence: K. Lazarević, Department of Biomedical Sciences, State University of Novi Pazar, Vuka Karadžića bb, 36300 Novi Pazar, Serbia. E-mail: konstansalazarevic@gmail.com

https://doi.org/10.21101/cejph.a5922

\section{INTRODUCTION}

According to the WHO estimates, mortality from injuries in the world is steadily decreasing from $77.8 / 100,000$ in 2000 to $64.4 / 100,000$ people in 2016. Despite this improvement, injuries still accounted for about 4.9 million or $9 \%$ of all deaths in 2016 , and at the same time, nearly 2,000 children under the age of 14 die each day as a result of injuries (1).

The leading external causes of death differed by country, age group, sex, and residence of children. Mortality rate from injuries among children is the highest in low-income countries, infants have the highest death rates from burns and suffocations, older adolescents' mortality rate is the highest in traffic accidents, boys die more often than girls with exception of fire related deaths, and the risk of death from injury is higher among rural than urban children (2).

The Republic of Serbia is a country in the Southeast Europe with the total population of 7,186,862 citizens and with one of the oldest populations in Europe. Children under age of 14 account for $14.2 \%$ of the total population (3).

Over the last two decades drastic political and socioeconomic changes have occurred in Serbia, such as the break-up of former Yugoslavia, high inflation with decline of the living standard, rapid transition to market economy, and the 2007-2008 global financial crisis. In 2007, the World Bank classified the Republic of Serbia as an upper-middle-income country (4).
In Europe, large differences in the mortality rates and the decline of mortality rates from injury among children aged 0-14 years were recorded. In 2015, mortality rate from injuries was 6.2 times higher in low- and middle-income countries than in high income countries (5).

The external causes of death are preventable and predictable (2). To our knowledge, there are no available data about trend and rate of fatal injury among children aged 1-14 years in Serbia, and on the national level there are no injury prevention policies, strategies and/or plans of action.

Therefore, studies related to mortality from injury by age group and gender, and causes of death for each European country individually, especially from middle-income countries, are necessary for the creation and implementation of nationwide preventive strategies $(5,6)$.

The aim of this paper is to determine the trend, rate, and the most common external causes of death among children aged 1-14 in the 1997-2016 period in the Republic of Serbia.

\section{MATERIALS AND METHODS}

The research included the population of children aged 1-14 years from Central Serbia and the Province of Vojvodina excluding the Province of Kosovo and Metohija (data unavailable). 
The mortality database for the 1997-2016 period was obtained from the Statistical Office of the Republic of Serbia.

The causes of death as result of external causes were classified according to the World Health Organization International Classification of Diseases, Tenth Revision (ICD 10): transport accidents (V01-V99; Y85), accidental drowning and submersion (W65-W74), suffocation (W75-W84), falls (W00-W19), electric trauma (W85-W87), exposure to fire, smoke and heat (W92-W93; X00-X15), accidental poisoning (X40-X49), and other deaths due to external causes (W20-W64; W88-W91; W94-W99; X16-X39; X58-X59; Y35-Y36; Y40-Y89), due to intentional injuries: intentional self-harm (suicides) (X60-X84; Y87.0) and assault (X85-Y09), as well as deaths due to events of undetermined intent (Y10-Y34; Y87.2; Y89.9).

Data were grouped according to gender and age categories (1-4 years, 5-9 years, and 10-14 years) and analysed in terms of number of deaths, and cause of external death.

To compare probabilities of mortality from external causes between boys and girls, relative risks (RR) with 95\% confidence intervals in the year 1997 and 2016 are calculated (7).

Mortality rates (MR) were expressed as number of deaths per 100,000 children, stratified by age group and sex. To calculate sex and age specific mortality rates, population denominator data were obtained from the national censuses (2002 and 2011), and for inter-census years we used estimates published online by the Statistical Office of the Republic of Serbia*.

The trend in MR and the corresponding $95 \%$ confidence intervals were computed using the Joinpoint Regression Program version 4.2.0.2. (Statistical Methodology and Applications Branch, Surveillance Research Program, US National Cancer Institute).

This analysis fits a series of straight lines (time periods) on a log scale to the MRs and detects the points in time (calendar years) where significant changes in trend occur. Annual percentage change (APC) in MRs and the corresponding 95\% confidence interval are computed for each defined time period using generalized linear model assuming a Poisson distribution. We used MR as the dependent variable and calendar year as the independent variable. The optimal number of joinpoints was identified using the Monte Carlo permutation method (8). P-values $<0.05$ were considered significant.

\section{RESULTS}

Over the 20-year study period, a total of 4,722 deaths of children aged 1-14 was reported. Among these, 1,388 children (934 boys and 454 girls) died due to external causes (unintentional and intentional injuries). External causes of death comprised 29.4\% $(n=1,388)$ of all deaths - from $34.8 \%(n=127)$ in 1997 to $21.8 \%$ $(\mathrm{n}=27)$ in 2016 .

Deaths due to unintentional injury accounted for $86.0 \%$ $(n=1,193)$ of all injury related deaths, intentional deaths for $8.4 \%$ $(\mathrm{n}=117)$, and deaths due to an event of undetermined intent accounted for $5.6 \%(n=78)$.

External causes of death contributed to all registered deaths $19.8 \%,(n=355), 33.2 \%(n=447)$, and $37.0 \%(n=586)$ in the

*http://www.stat.gov.rs/sr-latn/oblasti/stanovnistvo/procene-stanovnistva/

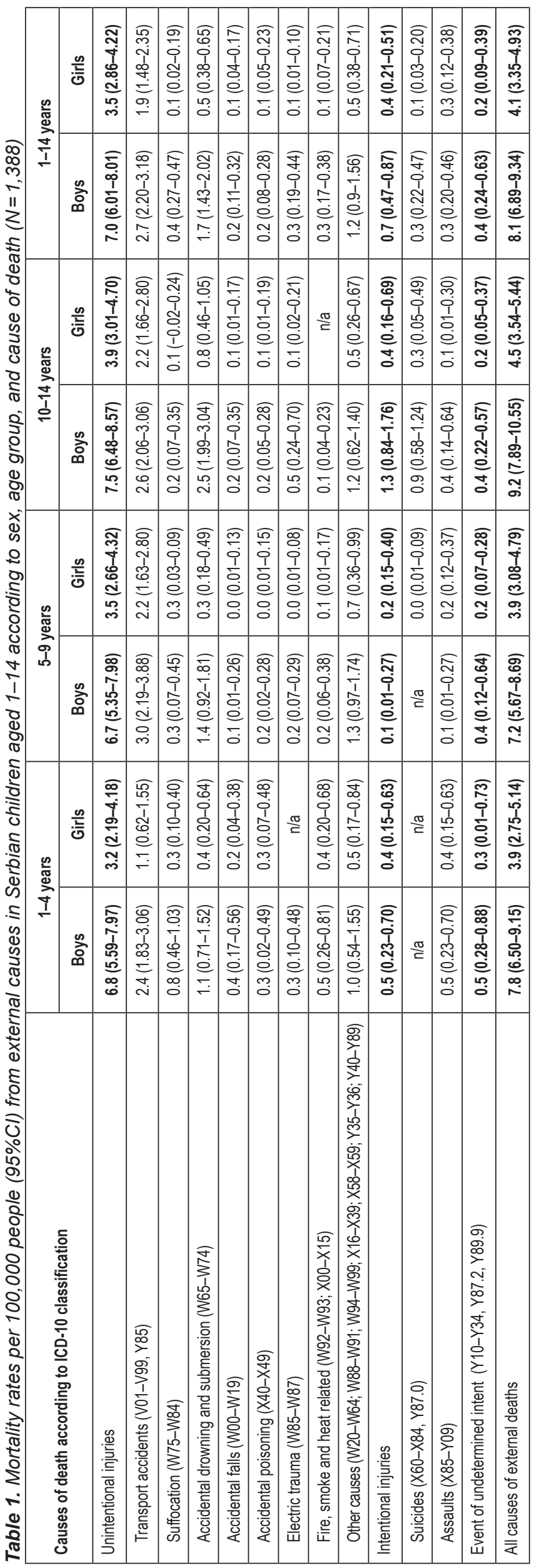


age groups 1-4, 5-9, and 10-14 years for both sexes, and $33.9 \%(n=934)$ among boys and $23.0 \%(n=454)$ among girls, respectively.

Table 1 shows mortality rates for all injury-caused deaths $(95 \%$ $\mathrm{CI})$, according to age group and the causes of death between 1997 and 2016.

The rate of external causes of death among children aged 1-14 was two times higher in boys $(8.1 ; 95 \%$ CI 6.89-9.34) compared to girls $(4.1 ; 95 \%$ CI $3.35-4.93)$.

Over the study period, the most common cause of deaths from external causes among children aged 1-14 years were transport accidents $-37.6 \%(n=522)$, followed by accidental drowning $18.2 \%(n=252)$.
Mortality rate from transport accident was higher among boys $(2.7 ; 95 \%$ CI $2.20-3.18)$ than among girls $(1.9 ; 95 \% \mathrm{CI}$ 1.48-2.35).

Transport accident-related deaths accounted for $11.0 \%$ $(n=522)$ of all child deaths $(n=4,722)$. More than half of child deaths $(273$ or $52.3 \%$ ) in road accidents are classified as V99 (unspecified transport accident) or V89 (motor or non-motor vehicle accident, type of vehicle unspecified). Deaths due to transport accidents were mainly related to injury to pedestrians (V01-V09; 119 or $22.8 \%$ ) or injury to car occupants (V49-V79; 77 or $14.7 \%)$.

Accidental submersion and drowning were the second most frequent unintentional cause of deaths in boys and girls aged

Table 2. Change of mortality rates per 100,000 population due to external causes of death according to sex and age group in Serbia from 1997 to 2016

\begin{tabular}{|c|c|c|c|c|c|c|c|}
\hline $\begin{array}{l}\text { Age group } \\
\text { (years) }\end{array}$ & Sex & $\begin{array}{c}\text { Initial } 1997 \\
\text { (MR) }\end{array}$ & $\begin{array}{c}\mathrm{RR}(95 \% \mathrm{Cl}) \\
\mathrm{p} \text {-value }\end{array}$ & $\begin{array}{c}\text { Final } 2016 \\
\text { (MR) }\end{array}$ & $\begin{array}{c}\mathrm{RR}(95 \% \mathrm{Cl}) \\
\mathrm{p} \text {-value }\end{array}$ & $\operatorname{APC}(95 \% \mathrm{Cl})$ & $\mathrm{p}$-value \\
\hline \multicolumn{8}{|c|}{ Unintentional injury (V01-V99; W00-W99; X00-X59; Y35-Y36; Y40-Y89) } \\
\hline $1-4$ & $\begin{array}{l}\text { Boys } \\
\text { Girls }\end{array}$ & $\begin{array}{c}10.7 \\
3.0\end{array}$ & $\begin{array}{c}3.5(1.3-9.5) \\
0.012\end{array}$ & $\begin{array}{l}2.2 \\
0.8\end{array}$ & $\begin{array}{c}2.8(0.3-27.1) \\
0.369\end{array}$ & $\begin{array}{c}-4.7(-7.2 \text { to }-2.1) \\
-10.8(-20.1 \text { to }-0.4)\end{array}$ & $\begin{array}{l}<0.001 \\
<0.001\end{array}$ \\
\hline $5-9$ & $\begin{array}{l}\text { Boys } \\
\text { Girls }\end{array}$ & $\begin{array}{l}11.2 \\
5.9\end{array}$ & $\begin{array}{c}1.9(0.9-3.7) \\
0.061\end{array}$ & $\begin{array}{l}2.3 \\
1.2\end{array}$ & $\begin{array}{c}1.9(0.3-10.3) \\
0.466\end{array}$ & $\begin{array}{l}-8.3(-10.6 \text { to }-5.9) \\
-13.0(-21.0 \text { to }-4.1)\end{array}$ & $\begin{array}{l}<0.001 \\
<0.001\end{array}$ \\
\hline $10-14$ & $\begin{array}{l}\text { Boys } \\
\text { Girls }\end{array}$ & $\begin{array}{l}11.0 \\
6.9\end{array}$ & $\begin{array}{c}1.6(0.9-2.9) \\
0.136\end{array}$ & $\begin{array}{l}3.3 \\
1.7\end{array}$ & $\begin{array}{c}1.9(0.5-7.6) \\
0.367\end{array}$ & $\begin{array}{l}-4.0(-6.3 \text { to }-1.7) \\
-5.8(-9.8 \text { to }-1.7)\end{array}$ & $\begin{array}{l}<0.001 \\
<0.001\end{array}$ \\
\hline $1-14$ & $\begin{array}{l}\text { Boys } \\
\text { Girls }\end{array}$ & $\begin{array}{l}11.0 \\
5.5\end{array}$ & $\begin{array}{c}1.9(1.3-3.0) \\
<0.001\end{array}$ & $\begin{array}{l}2.7 \\
1.3\end{array}$ & $\begin{array}{c}2.0(0.8-5.4) \\
0.148\end{array}$ & $\begin{array}{l}-5.4(-6.8 \text { to }-3.9) \\
-7.1(-9.0 \text { to }-5.1)\end{array}$ & $\begin{array}{l}<0.001 \\
<0.001\end{array}$ \\
\hline \multicolumn{8}{|c|}{ Intentional injury (X60-X90, Y87.0) } \\
\hline $1-4$ & $\begin{array}{l}\text { Boys } \\
\text { Girls }\end{array}$ & $\begin{array}{l}0.6 \\
0.6\end{array}$ & $\begin{array}{l}0.9(0.1-14.9) \\
0.960\end{array}$ & $\begin{array}{l}0.0 \\
0.8\end{array}$ & $\begin{array}{c}0.3(0.0-7.7) \\
0.478\end{array}$ & $\begin{array}{l}-0.2(-17.3 \text { to } 20.4) \\
2.2(-15.6 \text { to } 23.6)\end{array}$ & $\begin{array}{l}0.980 \\
0.817\end{array}$ \\
\hline $5-9$ & $\begin{array}{l}\text { Boys } \\
\text { Girls }\end{array}$ & $\begin{array}{l}0.9 \\
0.0\end{array}$ & $\begin{array}{l}4.7(0.2-98.5) \\
0.316\end{array}$ & $\begin{array}{l}0.0 \\
0.6\end{array}$ & $\begin{array}{c}0.3(0.0-7.7) \\
0.477\end{array}$ & $\begin{array}{l}-9.5(-21.1 \text { to } 3.7) \\
6.4(-10.2 \text { to } 26.0)\end{array}$ & $\begin{array}{l}0.140 \\
0.451\end{array}$ \\
\hline $10-14$ & $\begin{array}{l}\text { Boys } \\
\text { Girls }\end{array}$ & $\begin{array}{l}3.9 \\
0.8\end{array}$ & $\begin{array}{c}4.8(1.1-21.9) \\
0.043\end{array}$ & $\begin{array}{l}2.2 \\
0.6\end{array}$ & $\begin{array}{c}3.8(0.4-33.9) \\
0.234\end{array}$ & $\begin{array}{l}-10.1(-22.5 \text { to } 4.2) \\
-9.8(-24.9 \text { to } 8.3)\end{array}$ & $\begin{array}{l}0.148 \\
0.252\end{array}$ \\
\hline $1-14$ & $\begin{array}{l}\text { Boys } \\
\text { Girls }\end{array}$ & $\begin{array}{l}2.0 \\
0.5\end{array}$ & $\begin{array}{l}4.1(1.2-14.4) \\
0.028\end{array}$ & $\begin{array}{l}0.8 \\
0.7\end{array}$ & $\begin{array}{c}1.3(0.3-5.6) \\
0.765\end{array}$ & $\begin{array}{l}-10.0(-19.0 \text { to } 0.10) \\
-2.1(-15.3 \text { to } 13.1)\end{array}$ & $\begin{array}{l}0.054 \\
0.759\end{array}$ \\
\hline \multicolumn{8}{|c|}{ Event of undetermined intent (Y10-Y34, Y87.2, Y89.9) } \\
\hline $1-4$ & $\begin{array}{l}\text { Boys } \\
\text { Girls }\end{array}$ & $\begin{array}{l}1.1 \\
0.0\end{array}$ & $\begin{array}{c}4.7(0.1-14.9) \\
0.321\end{array}$ & $\begin{array}{l}0.0 \\
0.0\end{array}$ & $\begin{array}{l}0.9(0.2-47.4) \\
0.975\end{array}$ & $\begin{array}{l}-18.6(-31.7 \text { to }-3.1) \\
-18.8(-29.9 \text { to }-6.0)\end{array}$ & $\begin{array}{l}<0.001 \\
<0.001\end{array}$ \\
\hline $5-9$ & $\begin{array}{l}\text { Boys } \\
\text { Girls }\end{array}$ & $\begin{array}{l}0.0 \\
0.5\end{array}$ & $\begin{array}{c}0.3(0.1-7.7) \\
0.479\end{array}$ & $\begin{array}{l}0.0 \\
0.0\end{array}$ & $\begin{array}{l}0.9(0.2-47.4) \\
0.975\end{array}$ & $\begin{array}{l}-20.5(-31.7 \text { to }-7.6) \\
-18.1(-27.7 \text { to }-7.2)\end{array}$ & $\begin{array}{l}<0.001 \\
<0.001\end{array}$ \\
\hline $10-14$ & $\begin{array}{l}\text { Boys } \\
\text { Girls }\end{array}$ & $\begin{array}{l}0.0 \\
0.0\end{array}$ & $\begin{array}{c}1.0(0.0-48.4) \\
0.984\end{array}$ & $\begin{array}{l}0.0 \\
0.6\end{array}$ & $\begin{array}{c}0.3(0.1-7.7) \\
0.479\end{array}$ & $\begin{array}{l}-4.5(-19.7 \text { to } 13.6) \\
-9.7(-22.8 \text { to } 5.5)\end{array}$ & $\begin{array}{l}0.584 \\
0.186\end{array}$ \\
\hline $1-14$ & $\begin{array}{l}\text { Boys } \\
\text { Girls }\end{array}$ & $\begin{array}{l}0.3 \\
0.2\end{array}$ & $\begin{array}{c}1.9(0.2-20.9) \\
0.602\end{array}$ & $\begin{array}{l}0.0 \\
0.2\end{array}$ & $\begin{array}{c}0.3(0.1-7.7) \\
0.478\end{array}$ & $\begin{array}{l}-13.8(-24.5 \text { to }-1.5) \\
-18.7(-28.2 \text { to }-8.0)\end{array}$ & $\begin{array}{l}0.031 \\
0.002\end{array}$ \\
\hline \multicolumn{8}{|c|}{ All causes of external deaths } \\
\hline $1-4$ & $\begin{array}{l}\text { Boys } \\
\text { Girls }\end{array}$ & $\begin{array}{l}12.4 \\
3.6\end{array}$ & $\begin{array}{c}3.4(1.4-8.4) \\
0.008\end{array}$ & $\begin{array}{l}2.2 \\
1.6\end{array}$ & $\begin{array}{c}1.4(0.2-8.5) \\
0.706\end{array}$ & $\begin{array}{l}-5.1(-7.4 \text { to }-2.7) \\
-10.6(-20.3 \text { to } 0.3)\end{array}$ & $\begin{array}{l}<0.001 \\
<0.001\end{array}$ \\
\hline $5-9$ & $\begin{array}{l}\text { Boys } \\
\text { Girls }\end{array}$ & $\begin{array}{c}12.0 \\
6.4 \\
\end{array}$ & $\begin{array}{c}1.9(1.0-3.6) \\
0.052 \\
\end{array}$ & $\begin{array}{l}2.9 \\
1.9 \\
\end{array}$ & $\begin{array}{c}1.2(0.3-5.6) \\
0.767 \\
\end{array}$ & $\begin{array}{l}-8.6(-10.0 \text { to }-7.2) \\
-8.7(-12.1 \text { to }-5.1)\end{array}$ & $\begin{array}{l}<0.001 \\
<0.001\end{array}$ \\
\hline $10-14$ & $\begin{array}{l}\text { Boys } \\
\text { Girls }\end{array}$ & $\begin{array}{l}14.9 \\
7.8\end{array}$ & $\begin{array}{c}1.9(0.6-5.5) \\
0.024\end{array}$ & $\begin{array}{l}5.5 \\
2.9\end{array}$ & $\begin{array}{c}1.9(0.7-5.5) \\
0.244\end{array}$ & $\begin{array}{l}-4.3(-6.4 \text { to }-2.2) \\
-6.1(-10.2 \text { to }-1.8)\end{array}$ & $\begin{array}{l}<0.001 \\
<0.001\end{array}$ \\
\hline $1-14$ & $\begin{array}{l}\text { Boys } \\
\text { Girls }\end{array}$ & $\begin{array}{l}13.2 \\
6.2\end{array}$ & $\begin{array}{c}2.1(1.5-3.1) \\
<0.001\end{array}$ & $\begin{array}{l}3.5 \\
2.2\end{array}$ & $\begin{array}{c}1.6(0.7-3.5) \\
0.236\end{array}$ & $\begin{array}{l}-5.7(-6.9 \text { to }-4.4) \\
-6.8(-8.7 \text { to }-4.9)\end{array}$ & $\begin{array}{l}<0.001 \\
<0.001\end{array}$ \\
\hline
\end{tabular}

MR - mortality rate; $95 \% \mathrm{Cl}-95 \%$ confidence interval; RR - relative risk; APC - annual percentage change; $p<0.05$ - statistically significant 
$1-14$. Mortality rate due to accidental drowning was three times higher among boys $(1.7 ; 95 \%$ CI $1.43-2.02)$ compared to girls $(0.5 ; 95 \%$ CI $0.38-0.65)$. A large number of cases of drowning and submersion were not specified, but among the specified causes of drowning and submersion, most of the deaths (90 or 35.7\%) occurred in natural waters (W69-W70).

Suffocation and smoke and heat related unintentional deaths were significant external causes of death among children aged $1-4$, with 29 cases both or more than $10 \%(n=58)$.

Suicides among adolescents aged 10-14 accounted for $8.9 \%$ $(\mathrm{n}=52)$ of all external causes of deaths $(\mathrm{n}=586)$. Mortality rate for boys was 0.9 per 100,000 (95\% CI 0.58-1.24) and for girls it was 0.3 per $100,000(95 \%$ CI $0.05-0.49)$. The majority of deaths by suicide were the result of hanging $-45.3 \%(n=24)$ or use of firearms $-18.8 \%(n=10)$. Also $43.8 \%(n=28)$ of all assaults were results of firearm use. So, almost one third $-32.5 \%(n=38)$ of intentional injuries were results of firearm use.

Mortality rate from assaults was the highest among children aged $1-4$ years $(0.5$ per 100,$000 ; 95 \%$ CI $0.23-0.70$ for boys and $0.4 ; 95 \%$ CI $0.15-0.63$ for girls), and boys aged $10-14$ (0.4 per 100,000; 95\% CI 0.15-0.63).

Table 2 shows RR and APCs from external causes of death with $95 \%$ confidence interval $(p<0.05)$ according to gender and age groups.

Mortality rate from external causes among children aged $1-14$ is decreasing with APC of $-5.7 \%$ for boys and $-6.8 \%$ for girls, and in the case of unintentional injury $-5.4 \%$ for boys and $-7.1 \%$ for girls.

Mortality rate from intentional injury is also decreasing, $-10 \%$ for boys and $-2.1 \%$ for girls, but these changes are not statistically significant ( $\mathrm{p}=0.054$ for boys, and $\mathrm{p}=0.759$ for girls $)$.
The highest decline was noted concerning the events of undetermined intent for boys $(\mathrm{APC}=-13.8)$, and for girls $(\mathrm{APC}=$ -18.7).

Probability of death due to external causes was higher among boys than girls, significantly in $1997(\mathrm{RR}=2.1 ; 95 \% \mathrm{CI} 1.5-3.1$; $\mathrm{p}<0.001)$ and insignificantly in $2016(\mathrm{RR}=1.6 ; 95 \%$ CI $0.7-3.5$; $\mathrm{p}=0.24)$.

Figure 1 and Figure 2 show trend of MR per 100,000 children for two most common external causes of death: transport accidents and drowning and submersion.

A significant decrease in the mortality rates was observed for transport accident as well as for accidental drowning and submersion related deaths (by $-4.3 \%$ annually) where transport accident-related deaths showed a notable change in decreasing trend, from $-3.6 \%$ annually in the $1997-2009$ period to $-15.5 \%$ annually in the 2009-2016 period.

\section{DISCUSSION}

It is well known that risk of injury is influenced by factors such as temperament, personality and cognitive development of the child, as well as by quality and style of parenting supervision (9). Mortality due to external causes of death was twice as high for boys compared to girls (2), whereas boys are more prone to risky behaviour compared to girls and usually have a higher level of activity (10).

In the present study, mortality rate from external causes among Serbian children aged 1-14 dropped 3-5 times, particularly due to decreases in mortality from transport accidents and drowning. Similarly, in the study by Kyu et al. mortality rate from injury

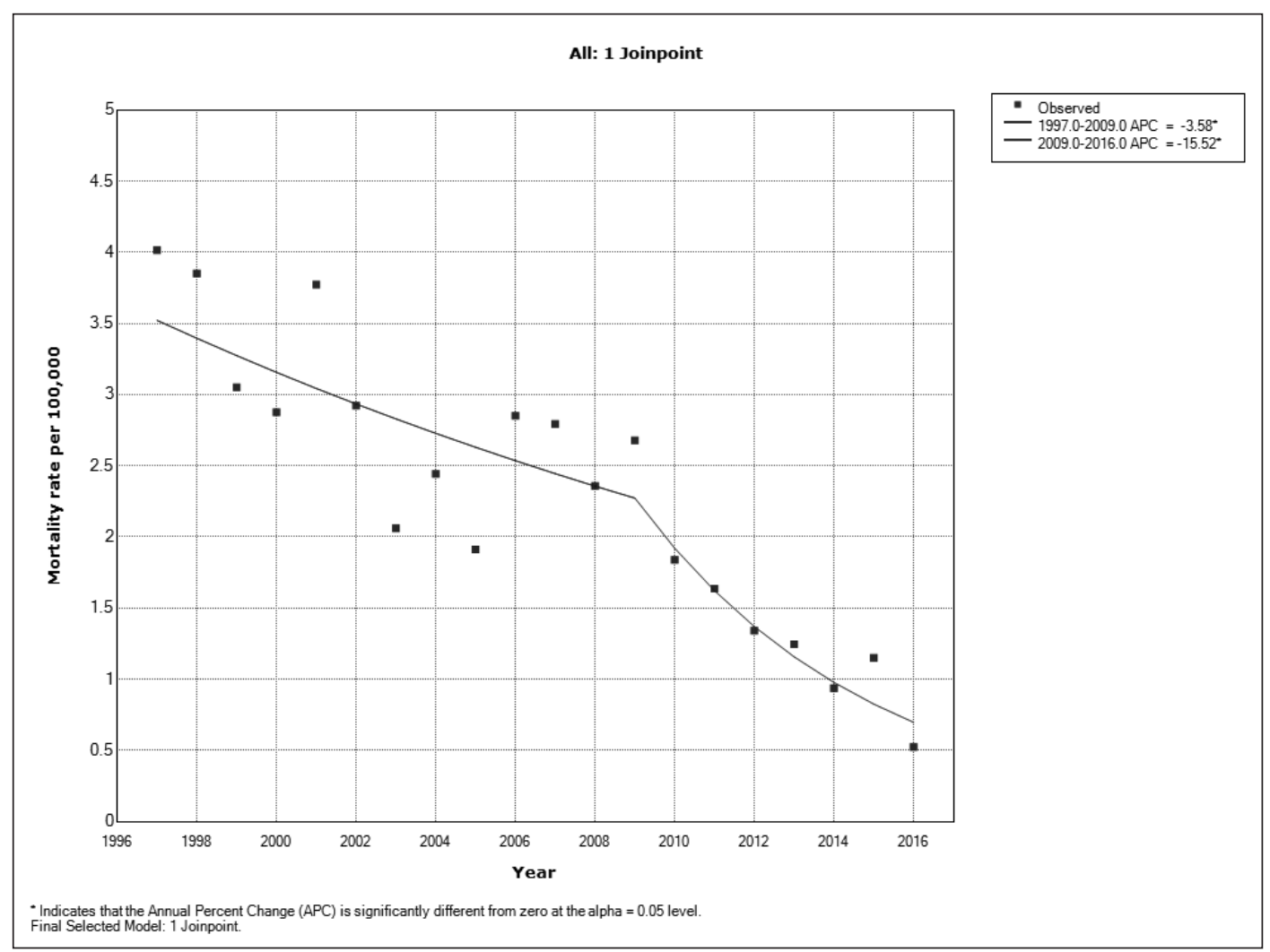

Fig. 1. Transport accident-related mortality trend in children aged 1-14 in Serbia, 1997-2016. 


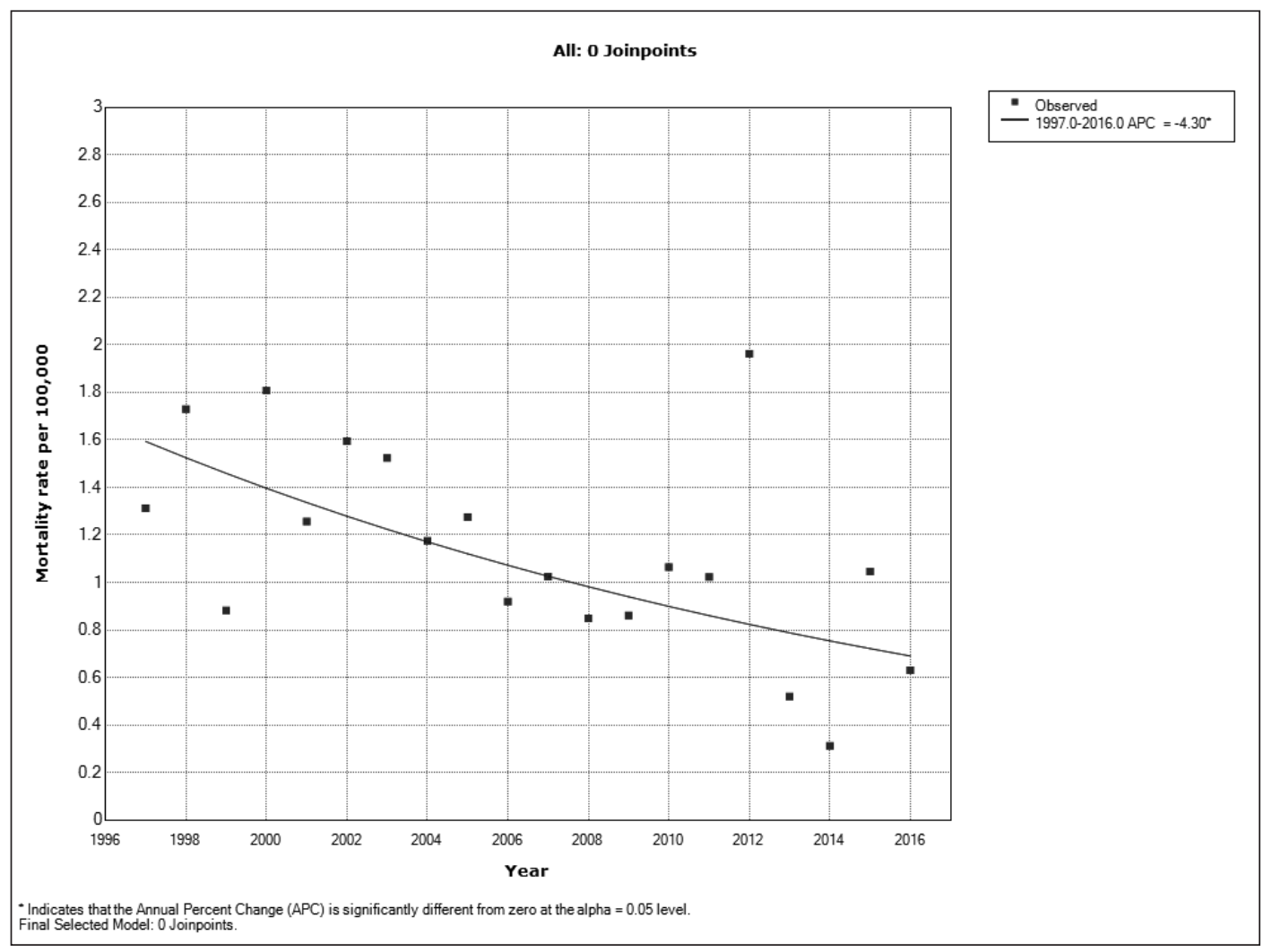

Fig. 2. Drowning and submersion-related mortality trend in children aged 1-14 years in Serbia, 1997-2016.

among children aged 5-14 years in the WHO European Region dropped almost 3 times in 2016 compared to 1990 ( 7.5 vs. 22.5 per 100,000 children) or 8.8 vs. 2.9 per 100,000 children for transport injuries and 6.5 vs. 1.8 per 100,000 children for drowning (11).

The observed decline in child deaths in transport accidents in Serbia is probably the result of the implementation of a new law on traffic safety, as well as improvements in the condition and safety of the national road network financed by the World Bank "Road Rehabilitation and Safety Projects". Investment in road rehabilitation, pavement widening, works concerning traffic signalization, traffic reduction measures etc., starting 2013, is seen as an important step to improve overall road safety in Serbia including prevention of road injuries (12).

Some parts of the new traffic law with amendments in the 2010-2019 period refer directly to the safety of children in traffic (lower speed limits for vehicles around schools $<30 \mathrm{~km} / \mathrm{h}$, utilization of appropriate child safety devices and seat belts, recommendation for children to wear a helmet when riding a bicycle).

Our results showed that transport injuries related deaths among Serbian children comprised $11 \%$ of all deaths among children, whereas in $27 \mathrm{EU}$ countries these percentages varied from $4 \%$ in UK and Sweden to over $14 \%$ in Latvia and around $13 \%$ in Croatia and Finland in the 2013-2015 period (13). According to data provided by the Ministry of Internal Affairs of the Republic of Serbia, in 2010 it noticed greater reduction in the number of road crashes, compared to the previous year after the introduction of the new law on traffic safety (14). This fact is consistent with the results of our research, where the decrease in traffic accident-related mortality is significantly higher starting from 2009 ( $-3.6 \%$ annually until 2009 , and $-15.5 \%$ annually in the period 2009-2016).
In Europe, nearly half (48\%) of all traffic accident-related deaths of children aged $0-14$ occurred in vehicle occupants, $30 \%$ were pedestrians, $13 \%$ cyclists, and only $9 \%$ of child deaths on the roads was listed as other or unknown (13). We can assume that the number of children aged 1-14 dying as pedestrians (22.8\%), and car occupants $(14.7 \%)$ in Serbia is actually far greater than reported in our study, taking into account that the cause of death in more than half of the children dying in traffic accidents was listed as other or unknown.

Pedestrian injuries among children mostly occur when school children walk home from school unaccompanied by adults (15). For this reason, parents in Serbia prefer to drive their children to school. At the same time, the experiences of European Union countries show that this is not good practice, because walking to school helps the children to develop road safety skills and also improves their ability to anticipate other road users (13).

To improve school children behaviour in traffic, the Road Safety Agency of Serbia launched the campaign "Attention Now!" in 2011 with promotion in media and schools, and around high-risk locations and streets. In 2015, the Road Safety Agency website introduced an animated character, a 10-year-old boy called "Pažljivko" ("Careful boy") who knows traffic rules well and transfers his knowledge to younger friends. This year, an animated film featuring this character collected over 1 million views on YouTube (16).

Accidental drowning is the second leading cause of death worldwide among boys 5-14 years of age, in 2016 (2) and among children aged 1-14 years in our study. The studies of unintentional drowning mostly focused on children under age of 5 in swimming pools (17). An annual educational campaign on adequate supervision of children around water, swimming and water safety 
instruction and the implementation of low pool fencing has proven to be effective measure to prevent accidental drowning $(17,18)$. Unfortunately, as far as we know, none of these measures is being implemented at the national level in Serbia.

Serbia is a country rich in rivers and lakes and recreational use of these water sources (for swimming, fishing, walking, and picnicking) pose a special risk for drowning of mostly older children. There was little research that investigated the epidemiology of drowning in rivers, as well as the effectiveness of drowning prevention measures, even in countries like Australia, where drowning in rivers is common (19). In Serbia, rural aquatic settings of rivers or lakes used for recreation do not meet the legal requirements prescribed by the WHO as "Guidelines for safe recreational water environments" (20). Their use should urgently be prohibited, and such illegal water recreation locations must be fenced off and marked with clearly visible signposts prohibiting their use.

The leading causes of injuries varied between age groups. Children under the age of 5 are more likely to be injured at home (21). They are very curious, and often come in contact with hazardous objects or play with fire, so burns and smoke inhalation are important causes of mortality (2). Suffocation by airway obstruction occurs with food (candy, grapes, nuts, etc.) or objects (small parts of toys, buttons, coins, pillow, blanket etc.) and contributes to about $10 \%$ of all injury related deaths among Serbian children aged 1-4 years. However, it is evident that mortality rate was the lowest in European countries with implementation of evidence-based national level policies relating to suffocation prevention (22).

It is a matter of concern that even if deaths due to electric injuries worldwide are very rare among children and younger adolescents (23), in our study they are the third leading cause of unintentional death among 10-14 years old boys. Domestic environments with properly maintained electrical devices, electrical wires or equipment may eliminate risk for electrical injury among adolescents (23).

Based on the UNICEF Serbia (2017) estimates, many children in Serbia were exposed to neglect and various forms of abuse and violence in all segments of social life: family home, kindergarten, school, institutions (for children without parental care, for children with disabilities, correctional institutions), etc. (24). The Balkan epidemiological study on abuse and neglect of children noted that nearly $70 \%$ of children in Serbia were exposed to some form of physical or emotional abuse (25). Unfortunately, many cases of non-fatal violence against children remain undetected because Serbia does not have official protocols for medical examination of abused children and national guidelines for medical investigation of abused children (26). Preventing and protecting children from violence has been set as one of the key priorities in the national policies adopted in Serbia, the General Protocol for the Protection of Children from Abuse and Neglect (2005) and the National Strategy for Preventing and Protecting Children from Violence (2009) for more than a decade. In 2017, a new policy cycle in preventing and protecting children from violence was initiated (24).

According to available data from 81 countries in the period 1990-2009, suicide rate in children aged 10-14 showed a minor decline for boys (1.61 to 1.52 per 100,000), whereas for girls it has shown a slight increase (0.85 to 0.94 per 100,000) (27). Kõlves and de Leo found from analysed data from 101 countries about suicide methods among children aged $10-14$ years that $74 \%$ of children died from hanging and $13 \%$ from firearms (28). The most common methods of suicide in our report are hanging (44.2\%) and the use of firearms (18.2\%) while almost one third (32.5\%) of external causes of death were results of firearm use.

The high presence and availability of firearms in the Balkans is a consequence of the conflict caused by the breakup of former Yugoslavia. For this reason, in March 2016, a new law on weapons and ammunition came into force, having significantly more stringent provisions on the possession and protection of firearms. It is expected that these legal measures will reduce the number of deaths from assaults in Serbia, including assaults and suicides of children.

\section{Study Limitations}

Although death registration in Serbia has been improved in the recent years, a large percentage of deaths in children $(5.6 \%)$ is still designated as an event of undetermined intent. Improvements in mortality data collection have urgent public health priority.

In Serbia, there are no data on the number of non-fatal injuries among the population, including children, so we cannot estimate whether the reduction in mortality from injuries was due to reduced injuries or due to better medical treatment of trauma.

\section{CONCLUSION}

In Serbia, mortality of children due to external causes in the researched period is reduced, owing to reduced death rate from traffic accidents and accidental drowning and submersion. However, external causes still presented a fifth of all causes of death in Serbian children and remain a significant cause of death in children. Prevention policies, strategies and/or plans of action to reduce mortality from external causes in Serbia are needed.

\section{Acknowledgement}

Presented results are the part of the project 44007 financed by the Ministry of Science and Technological Development, Republic of Serbia.

\section{REFERENCES}

1. World Health Organization. Global Health Estimates 2016. Deaths by cause, age, sex, by country and by region, 2000-2016 [Internet]. Geneva: WHO; 2018 [cited 2019 Jun 12]. Available from: https:/www.who.int/ healthinfo/global_burden_disease/estimates/en/index1.html.

2. Branche C, Ozanne-Smith J, Oyebite K, Hyder AA. World report on child injury prevention. Geneva: WHO; 2008.

3. Statistical Office of the Republic of Serbia. 2011 Census of population [Internet]. Belgrade: Statistical Office of the Republic of Serbia; 2016 [cited 2019 Jun 12]. Available from: http://popis2011.stat.rs.

4. The World Bank. Data. World Bank Country and Lending Groups [Internet]. Washington: The World Bank [cited 2019 Jun 10]. Available from: https://datahelpdesk.worldbank.org/knowledgebase/articles/906519world-bank-country-and-lending-groups.

5. Sethi D, Aldridge E, Rakovac I, Makhija A. Worsening inequalities in child injury deaths in the WHO European Region. Int J Environ Res Public Health. 2017 Sep 26;14(10):1128. doi: 10.3390/ijerph14101128.

6. Sengoelge M, Leithaus M, Braubach M, Laflamme L. Are there changes in inequalities in injuries? A review of evidence in the WHO European 
Region. Int J Environ Res Public Health. 2019 Feb 22;16(4):653. doi: 10.3390/ijerph16040653.

7. Altman DG. Practical statistics for medical research. London: Chapman and Hall; 1991

8. Kim HJ, Fay MP, Feuer EJ, Midthune DN. Permutation tests for joinpoint regression with applications to cancer rates. Stat Med. $2000 \mathrm{Feb}$ 15;19(3):335-51. Erratum in Stat Med. 2001 Feb 28;20(4):655.

9. Schwebel DC, Gaines J. Pediatric unintentional injury: behavioral risk factors and implications for prevention. J Dev Behav Pediatr. 2007 Jun;28(3):245-54

10. Udry JR. Why are males injured more than females? Inj Prev. 1998 Jun;4(2):94-5.

11. Kyu HH, Stein CE, Boschi Pinto C, Rakovac I, Weber MW, et al. Causes of death among children aged 5-14 years in the WHO European Region: a systematic analysis for the Global Burden of Disease Study 2016. Lancet Child Adolesc Health. 2018;2(5):321-37.

12. The World Bank. Serbia Road Rehabilitation and Safety Project [Internet] Washington: World Bank [cited 2021 May 20]. Available from: https:// projects.worldbank.org/en/projects-operations/project-detail/P127876.

13. Adminaite D, Jost G, Stipdonk H, Ward H, Calinescu T. Reducing child deaths on European roads. PIN flash report 34 [Internet]. Brussels: ETSC; 2018 [cited 2018 Jun 12]. Avaible from: https://etsc.eu/reducing-childdeaths-on-european-roads-pin-flash-34\%.

14. Vranes AJ, Mikanovic VB, Lazovic JM, Kosanovic V. Road traffic safety as a public health problem: evidence from Serbia. J Transp Health. 2018 Mar;8:55-62.

15. Feng XY, Nah SA, Lee YT, Lin YC, Chiang LW. Pedestrian injuries in children: who is most at risk? Singapore Med J. 2015;56(11):618-21

16. Republic of Serbia. Road Traffic Safety Agency. Preventive activities [Internet]. Belgrade: Road Traffic Safety Agency [cited 2018 Jun 12]. Avaible from: http://www.abs.gov.rs/en/preventive-activities\#0.

17. World Health Organization. Global report on drowning: preventing a leading killer. Geneva: WHO; 2014.

18. Mott TF, Latimer KM. Prevention and treatment of drowning. Am Fam Physician. 2016;93(7):576-82.
19. Peden AE, Franklin RC, Leggat PA. The hidden tragedy of rivers: a decade of unintentional fatal drowning in Australia. PLoS One. 2016;11(8):e0160709. doi: 10.1371/journal.pone.0160709.

20. World Health Organization. Guidelines for safe recreational water environments. Vol. 1, Coastal and fresh waters. Geneva: WHO; 2003.

21. Sengoelge M, Hasselberg M, Laflamme L. Child home injury mortality in Europe: a 16-country analysis. Eur J Public Health. 2011;21(2):166-70.

22. MacKay M, Vincenten J. Child Safety Report Card 2012: Europe summary for 31 countries. Birmingham: European Child Safety Alliance, Eurosafe; 2012.

23. Byard RW, Hanson KA, Gilbert JD, James RA, Nadeau J, Blackbourne $\mathrm{B}$, et al. Death due to electrocution in childhood and early adolescence. J Paediatr Child Health. 2003;39(1):46-8.

24. UNICEF. Violence against children in Serbia: Determinants, factors and interventions. Belgrade: UNICEF; 2017.

25. Hanak N, Tenjović L, Išpanović-Radojković V, Vlajković A, Beara M. Epidemiological research of violenxce against children in families in Serbia. Temida. 2013;16(2). (In Serbian.)

26. Duričić G, Milošević Z, Alempijević D, Radlović V, Medović R, Dučić S, et al. Social, clinical, and radiological characteristics of physical abuse of children under three years of age hospitalized in a tertiary health institution. Srp Arh Celok Lek. 2017;145(5-6):234-8.

27. Kolves K, De Leo D. Suicide rates in children aged 10-14 years worldwide: changes in the past two decades. Br J Psychiatry. 2014;205(4):2835 .

28. Kõlves K, de Leo D. Suicide methods in children and adolescents. Eur Child Adolesc Psychiatry. 2017;26(2):155-64.

Received August 20, 2019 Accepted in revised form May 5, 2021 